\title{
Effect of Financial Mix on Profitability of Quoted Beverage Firms in Nigeria
}

\section{Okolocha Chizoba Bonaventure*, John-Akamelu Racheal Chitom, Ezejiofor Raymond Asika}

Faculty of Management Sciences, Nnamdi Azikiwe University, Awka, Nigeria

\section{Email address:}

cb.okolocha@unizik.edu.ng (Okolocha C. B.), rachealchitom agmail.com (John-Akamelu R. C.),

thaddray4life@yahoo.com (Ezejiofor R. A.)

${ }^{*}$ Corresponding author

\section{To cite this article:}

Okolocha Chizoba Bonaventure, John-Akamelu Racheal Chitom, Ezejiofor Raymond Asika. Effect of Financial Mix on Profitability of Quoted Beverage Firms in Nigeria. International Journal of Accounting, Finance and Risk Management. Vol. 4, No. 4, 2019 , pp. 102-109. doi: 10.11648/j.jjafrm.20190404.11

Received: September 23, 2019; Accepted: October 11, 2019; Published: October 21, 2019

\begin{abstract}
This study examined the effect of financial mix on profitability of beverage firms in Nigerian quoted beverage companies. The empirical evidence on the effects of financial mix on firms' profit is, inconsistent and some are contradictory depending upon the statistical tools used and time-period. It is on this light that this study was set out to examine to ascertain the significant effect of short term debt and long term debt on profit of quoted beverage companies in Nigeria. This study employed ex-post facto research design. Regression analysis was used to test the hypotheses. The study observed that short term debt has positive significant influence on profit of quoted beverage companies in Nigeria while long term debt has no significant effect on profit of quoted beverage companies in Nigeria. Based on this, the study recommended among others that companies should prefer internal financing than external financing sources on debt financing also that corporate firms should rely more on equity financing for funds rising for their operation and minimize their borrowing operations in order to avoid bankrupt.
\end{abstract}

Keywords: Financial Mix, Long Term Debt, Short Term Debt and Profitability

\section{Introduction}

Financial mix decisions are crucial for the financial wellbeing of the firm. Financial distress, liquidation and bankruptcy are the ultimate consequences lying ahead if any major misjudgment occurred following any financing decision of the firm's activity. One of the strategies a firm should look into is to lower the weighted cost of capital. This will increase net economic return, which eventually increases the firm's value [1]. Hence, maximizing the firm's value is the focal point for every financing decision made by the management of the company. The management of the firm operating in the very uncertain world has a tough task ahead in achieving the best financial mix. However, the key to choosing an appropriate and acceptable level of financial leverage is still debatable by the top management of a firm.

Many theories and much empirical evidence in providing optimal financial mix exist in the real world. Yet, this is still a cloudy area and with no specific guidelines to assist financial officers in attaining an efficient mixture of debt and equity. Thus, only clues and calculated judgment plus some understanding of financial theory are possible tools to be applied in facilitating how the financing mix affects the firm's value, profitability and its stock price [2].

Modigliani and Miller in Pons-Sanz, Zuta, Venezia, Ravid and Ofer initiated the theory of financial mix in their influential seminar work on the effects of financial mix on the firm's value [3,4]. They demonstrate and finally conclude that the 'financial mix is an irrelevance' in a perfect financial market, considering the no-tax case in the 'pie model,' which literally means that the firm's value is independent of its financing or financial structure. They argue that the size of the pie does not depend on how it is sliced, but depends only on the level and risk of its future cash flows. This 'tax shield' allow firms to pay lower taxes than they should if equity financing is used, thus attaining optimal capital structure through tax saving. Financial distress will include bankruptcy and non-bankruptcy cost. 
The trade-off theory suggests that optimal capital structure can be attained. However, firms should take appropriate actions in balancing between the tax benefits of higher debt and the greater possibility of financial distress costs, while aiming to optimize their overall value $[3,4]$.

However, the agency costs only arise when the risk of defaults payment exists. Even though the agency costs of debt are burdensome, they are the solution towards obtaining external funds at a lower rate. The choice of financial mix brings signals to outside investors through the information of insiders. Ross assumes that managers (the insiders) know the true distribution of firms' returns, but investors do not [5]. If managers decide to add more debt into financial mix, investors interpret this as a signal of high future cash flows and the firm is committed towards its contractual obligation. Thus, this will show a higher level of confidence that the management has towards the firm's prospect in the near future. However, if managers decide to finance the firm by issuing new equity, this signals that management is lacking in confidence towards future prospects of the firm. Accordingly, it concludes that investors take larger levels of debt as a signal of higher quality and that profitability and leverage are thus positively related [6].

The purpose of this present study is to determine the relationship between financial mix and net profit after tax. This will clarify the extent of optimal debt and equity used in financing the firms' activity in emerging markets, such as Nigeria. This study explains the relation between financial mix profitability, and also sheds light on the financial mix in food and beverage industries in Nigeria and how to lead the financial managers in determining the right choices in the financial mix policy in the future.

Financial mix refers to the various financing options of the asset by a firm and it affects the profitability of such a firm [7]. Financial mix of a company is a subset of the financial structure: which in addition to the components of capital structure also includes short term debt and accounts payable. Financial mix in this case can be seen as a mix of a company's long term debt, short term debt, common equity and preferred equity (stock).

Finance mix is a major factor that affects the liquidity and the going concern of a business enterprise. After an idea has been conceived by an entrepreneur, there is need to also analyze the capital required for startup and means of financing the project. A good combination of sources of finance is expected to boost the profitability of an organization, but if not properly mixed, could have a negative effect on the profitability of the organization.

Many studies have also been carried out on financial mix on profit of firms; many of the studies found a significant positive effect between the equity and profitability such studies like; $[8,2,9]$. Despite the positive relationship with the profitability of manufacturing companies some researchers found negative effect between leverage and firm performance such studies like [10-12].

The results from the empirical evidence on the effects of financial mix on firms' profit are mixed, inconsistent and some are contradictory; ranging from positive, to negative, to statistical insignificant relationship depending upon the choice of measures of statistical tools used and time-period. Meanwhile, empirical evidences are inconclusive and therefore further research on the effect of financial mix on firms' profit developing country like in Nigeria.

The main objective of this study is to ascertain the effect of financial mix on profitability of quoted beverage firms in Nigeria. The specific objectives are;

1. To ascertain the significant effect of short term debt on profit of quoted beverage companies in Nigeria.

2. To determine the significant effect of long term debt on profit of quoted beverage companies in Nigeria.

\section{Review of Related Literature}

\subsection{Conceptual Framework}

\subsubsection{Financial Mix}

According to Wilcox financial mix is a term used in the corporate world to define a mix of equity to debt in a firm. In other words, this term is used to describe the formula that defines how much capital is being raised by debt and how much is being raised by equity [13]. There are many that believe this particular mix can have an impact on increasing or decreasing the value of the firm. The goal of any firm is to continuously increase the value. Any plans that are made, financial or otherwise, will be done with this goal in mind. Those in charge of the finances want to bring more wealth to the shareholders to keep them happy with the way the business is going [14]. For most firms, debt is considered a cheaper source of finance. This is because when a firm raises capital through debt the interest that they are charged is tax deductible. The same is not true for debt that is raised from capital. Because of this, a financial mix can actually help increase the value of the firm. It does this by altering the amount of debt that the firm has. This process will change the interest that the firm must pay out. If the interest that is paid out is decreased due to the new debt, then the income of the firm is increased. This leads to an increase in the value of the firm. This is why many in finance believe that financial mix plays a pivotal role in how successful a business is. However, there are risks. By increasing the debt of a firm, there is also the increased risk of bankruptcy. Those in charge of the finances must be certain that they know what they are doing if they are going to adjust the financial mix [13].

\subsubsection{Long Term Debt}

Long-term debt consists of loans and financial obligations lasting over one year. Long-term debt for a company would include any financing or leasing obligations that are to come due in a greater than 12-month period. Bonds are one of the most common types of long-term debt. Companies may issue bonds to raise funds for a variety of reasons. Bond sales bring in immediate income, but the company ends up paying for the use of investors' capital due to interest payments [15].

A company takes on long-term debt in order to acquire immediate capital. For example, startup ventures require 
substantial funds to get off the ground and pay for basic expenses, such as research expenses, Insurance, License and Permit Fees, Equipment and Supplies and Advertising and Promotion. All businesses need to generate income, and long-term debt is an effective way to get immediate funds to finance and operations.

Since debt sums tend to be large, these loans take many years to pay off. Companies with too much long-term debt will find it hard to pay off these debts and continue to thrive, as much of their capital is devoted to interest payments and it can be difficult to allocate money to other areas. A company can determine whether it has accrued too much long-term debt by examining its debt to equity ratio [16]. A low debt to equity ratio is a sign that the company is growing or thriving, as it is no longer relying on its debt and is making payments to lower it. It consequently has more leverage with other companies and a better position in the current financial environment. However, the company must also compare its ratio to those of its competitors, as this context helps determines economic leverage [17].

Long-term debt is not all bad, though, and in moderation, it is necessary for any company. Without incurring long-term debt, most companies would never get off the ground. Longterm debt is a given variable for any company, but how much debt is acquired plays a large role in the company's image and its future [18].

\subsubsection{Short Term Debt}

Short-term debt is an account shown in the current liabilities portion of a company's balance sheet. This account is made up of any debt incurred by a company that is due within one year. The debt in this liabilities account is usually made up of short-term bank loans taken out by a company, among other types [13].

Short-term debt, also known as short-term liabilities, refers to any financial obligation that is either due within a 12month period or due within the current fiscal year. The value of the short-term debt account is very important when determining a company's performance. If the account is larger than the company's cash and cash equivalents, this suggests that the company may be in poor financial health and does not have enough cash to pay off its short-term debts [19]. In addition to any short-term debts due within a year, there may be a portion of long-term debt that is also included in this account. This portion pertains to payments that must be made on any long-term debt throughout the year [19].

The first, and often the most common, type of short-term debt is a company's short-term bank loans. These types of loans arise on a business' balance sheet when the company needs quick financing in order to fund working capital needs. It's also known as a "bank plug," because a short-term loan is often used to fill a gap between longer financing options [20].

\subsubsection{Profit as a Company's Bottom Line}

Net income is a bottom line of companies, or the "bottom" figure on a company's income statement [2]. More specifically, the bottom line is a company's income after all expenses have been deducted from revenues. These expenses include interest charges paid on loans, general and administrative costs and income taxes. A company's bottom line can also be referred to as net earnings or net profits [2] Bottom line describes how efficient a company is with its spending and operating costs and how effectively it has been controlling total costs [21].

The bottom line is one of the most closely followed numbers in finance, and it plays a large role in ratio analysis and financial statement analysis. Shareholders look at the bottom line closely because it is the source of compensation to shareholders of the company, and if a company cannot generate enough profit to compensate owners, the value of shares will plummet. Conversely, if a company is healthy and growing, higher stock prices will reflect the increased availability of profits [22].

\subsection{Empirical Review}

Angahar and Ivarave, [8] investigated the effect of capital structure on corporate profit; evidence from cement manufacturing firms in Nigeria. It focused on quoted cement manufacturing firms in Nigeria from 2004-2013 using expost facto research design. Multi regression analysis was used to test the hypotheses. The findings were that, there exists a positive and significant effect of short term debt, long term debt and shareholder's fund on the profit of cement manufacturing firms in Nigeria.

Faris [2] provided insights into the way in which the capital structure and market power and capital structure and profitability are related. The study used sample data of fourteen banks listed on the Amman Stock Exchange for the period from 2005 to 2008 . The study examined the dependent variable, which are expressed by total debt deflated by total assets, while the independent variables are Tobin Q, Growth, Profitability, Size, Ownership, Risk and Tangibility ratio. The OLS estimation results indicate that, at lower and higher ranges of Tobin's Q, banks employ higher debt, and reduce their debt at intermediate range. The study also showed the saucer-shaped relation between capital structure and profitability because of the interplay of agency costs, costs of external financing and interest tax-shield.

Alhassan and Seidu [10] examined the financing decisions of 19 listed companies in comparison with 16 non-listed companies in Ghana. The study tested some hypotheses related to capital structure determinants and debt policy decisions. The study finds support for the pecking order hypothesis across all firms. The free cash flow hypothesis holds for long-term debt decisions across firms but not the capital structure decisions. The study does not find any significant differences between listed and non-listed firms in the application of debt.

Hassan, Faisal and Muhammad, [11] investigated the relationship between debt and profitability of firms with empirical evidence from the non-financial sector of Pakistan; using panel data of 10 years, ranging between 2003-2012. Return on Assets is used as the profitability measure and is the dependent variable, whereas; Short Term Debt to Asset, 
Long Term Debt to Asset, and Total Debt to Asset were used as independent variables, while Size, Sales Growth, and Growth Opportunity are used as control variables. Results indicate a significant but negative relationship between short term debt, long term debt, total debt, and return on assets.

Ubesie [23] investigated the effect of Nigerian banks' capital structure on the performance of conglomerates quoted on the floor of the Nigerian stock exchange from 2011 to 2015. The study identified four levels of dependent variables such as return on assets, ratio (ROA), return on equity ratio (ROE), assets turnover ratio (AT) and earnings per share whereas the independent variable is financial leverage. Descriptive statistics and the pooled ordinary least square (POLS) regression analytical method were used for data analysis. The study finds that capital structure has effect on both return on assets and asset turnover of the conglomerates but no effect on return on equity and earnings per share of the conglomerate. Robert and Mohamed (2015) investigated the relationship between financial leverage and the financial performance of listed firm in Kenya. The study used annual data for the period 2007 - 2011. Using various panel procedures, the study finds reasonably strong evidence that financial leverage significantly, and negatively, affects the performance of listed firms in Kenya and Tobin's Q.

Oladeji, Ikpefan, and Olokoyo [12] analyzed the impact of capital structure on firm performance in Nigeria from 2003 to 2012. Using data from six petroleum companies in Nigeria namely: Chevron Plc, Conoil Plc, Eterna Oil plc, Mobil Oil Plc, Oando Plc and Total Nigeria Plc, the study carried out a panel data analysis by using fixed effect estimation. The study found that a negative relationship exists between leverage and firm performance and the study established that a positive a relationship exists between three of the explanatory variables (firm's size, tax and lagged return of asset) and firm performance. The study therefore recommended that the management of the industry should rely more on equity financing as a way of funding their business. Amr [9] conducted a study that relates capital structure to corporate strategy in the Saudi context. A mixed methodology was adopted in this research that consists of quantitative analysis, supported by qualitative results where relevant. The findings of this thesis highlight three main points. First, the results on the determinants of capital structure demonstrate the significance of the cost of servicing debt, zakat, industry structures and the nature of assets in influencing leverage. The results indicate a negative relationship between leverage and profitability and a positive relationship between leverage and risk.

Lawal, Edwin, Monica and Adisa [24] examined the effect of capital structure on firm's performance with a case study of manufacturing companies in Nigeria from 2003 to 2012 with the purpose of providing a critical appraisal of the need and importance of capital structure. Descriptive and regression research technique was employed to consider the impact of some key variables such as Returns on asset (ROA), Returns on equity (ROE), Total debt to total asset (TD), Total debt to equity ratio (DE) on firm performance.
Secondary data was employed using data derived from ten (10) manufacturing companies. From the findings, it was observed that capital structure measures (total debt and debt to equity ratio) are negatively related to firm performance. Oyetade [25] presented empirical findings on the determinants of capital structure of selected sample population of non - financial firms of Nigeria. Data analysis involved the use SPSS quantitative software, with the adoption of Fixed Effect Estimation (FEE) and Ordinary Least Square (OLS) classical regression linear model. Major research findings of the study revealed the impact of liquidity in the leverage of Nigerian non - financial firms as a result of institutional factors such as size, return, growth, tangibility, liquidity and dividend on firms' impact and methods of financing. Naeem, Malik, Muhammad, \& Mehboob, [26] investigated whether working capital management affect the performance of non-financial listed firms in Pakistan. Panel econometric technique namely pooled ordinary least squares is used to estimate the relationship between working capital and firm performance. Data were taken from the annual reports of non-financial firms listed on the Karachi Stock Exchange Pakistan during 2007-2010. Three performance measures namely gross profit margin, return on asset, and return on equity are used to estimate the impact of working capital variables such as average age of inventory, average collection period, and average payment period. Empirical results indicate that average age of inventory is positively related to gross profit margin and return on asset, whereas it is negatively related to return on equity but the relationship is found insignificant.

Nyanamba, Nyangweso, \& Omari [27] conducted a study to determine the factors which influence the capital structure among microenterprises. The results identified the major determinants of the capital structure of micro-enterprises as being access to capital markets, size of the business, profitability of the business and lender's attitude towards the firm. Ann (2013) conducted a study to find the effect that financial structure has on the financial performance of conventional banks as well as that of Islamic banks. The study adopted a descriptive research design which involved a study of sampled conventional banks and Islamic banks. Secondary data was collected from five conventional banks and the two Islamic banks in Kenya. The study revealed that Islamic banks did not have debt to equity ratio in their financial structures mix, unlike conventional banks. Mwangi [28] analyzed the funding structure and financial performance of Deposit taking microfinance institutions in Kenya for the period 2011 to 2012. For the purpose of this study, the data was extracted from the published institution's annual audit reports and CBK's banks supervision annual reports for the 2 years under examination. This study used descriptive statistics to explain the main features of a collection of data in quantitative terms while correlation and linear regression analysis are used for analyzing the data. Financial performance was measured using return on assets while capital structure of DTMFIs was measured using customer's deposits and borrowings divided by total assets. 
Raheel, Shahnaz, Rauf, Bashir and Umara conducted a study on the relationship between capital structure and financial performance of selected listed firms in Pakistan. Regression analysis was adopted. The findings revealed that capital structure (proxied by DER) has a significant relationship with financial performance (proxied by ROE) of listed firms in Pakistan [29].

Thian [30] investigated the determinants of capital structure of financial service firms in China. Using a relative regression of accounting data for $36 \mathrm{~A}$-share financial listed companies over the years 2005-2009, an empirical study on determinants of capital structure in financial industry is conducted. The results show that profitability, firm size, nondebt tax shields, earnings volatility and non-circulating shares are significant influence factors in financial sector. Moreover, firm size is positively related to the corporate leverage ratio.

Robert [31] carried out a study on the gross profitability premium of firms. The study indicated that profitability, measured by gross profits-to-assets, has roughly the same power as book-to-market predicting the cross-section of average returns. These results are difficult to reconcile with popular explanations of the value premium, as profitable firms are less prone to distress, have longer cash flow durations, and have lower levels of operating leverage. Controlling for gross profitability explains most earnings related anomalies, and a wide range of seemingly unrelated profitable trading strategies.

Finance mix is a major factor that affects the liquidity and the going concern of a business enterprise. After an idea has been conceived by an entrepreneur, there is need to also analyze the capital required for startup and means of financing the project. A good combination of sources of finance is expected to boost the profitability of an organization, but if not properly mixed, could have a negative effect on the profitability of the organization.

The results from the empirical evidence on the effects of financial mix on firms' bottom line profit are mixed, inconsistent and some are contradictory; ranging from positive, to negative, to statistical insignificant relationship depending upon the choice of measures of financial mix, measures of bottom line profit, statistical tools used, sample composition, time-period and control variables. Apparently, empirical evidences available are still inconclusive and therefore no solid consensus. Empirical research on the effect of financial mix on firms' bottom line profit is available largely for developed nations and very few in Nigeria.

\section{Methodology}

\subsection{Research Design}

The research design that was employed in this study is the ex-post facto research design. An Ex-post Facto research determines the cause-effect relationship among variables. Expost Facto seeks to find out the factors that are associated with certain occurrence, conditions, events or behaviours by analyzing past events or already existing data for possible casual factors.

\subsection{Population of the Study}

The population of this study comprises of eight (8) Beverage firms listed on the floor of the Nigerian Stock Exchange. They include; Champion Brew Plc, GG Breweries Plc; Nigeria Breweries Plc; Guiness Nigeria Plc; Intl Breweries Plc; Jos Intl Brew Plc; Premier Brew Plc; 7-Up Bottling Co Nigeria.

\subsection{Method of Data Analysis}

The method of analysis of data for this study was done based on the data collected from publications of the Nigerian stock exchange (NSE), fact books and the annual report and accounts of the quoted beverage firms. Both the dependent and independent variables were computed from the data extracted from publications of the NSE. the formulated hypotheses were tested using regression analysis with aid of SPSS Version 20.

\subsection{Model Specification}

The specified simple regression estimated model takes the following form:

$$
\begin{gathered}
\operatorname{PAT}_{i t}=\mathrm{a}_{0}+\mu_{\mathrm{i}}+\beta_{\mathrm{I}} S T D_{\mathrm{it}} \beta_{2} L T D \sum \mathrm{e}_{\mathrm{it}} \\
\operatorname{PAT}_{\mathrm{it}}=\mathrm{a}_{0}+\mu_{\mathrm{i}}+\beta_{1} S T D_{\mathrm{it}} \sum \mathrm{e}_{\mathrm{it}} \\
\operatorname{PAT}_{\mathrm{it}}=\mathrm{a}_{0}+\mu_{\mathrm{i}}+\beta_{2} L T D_{\mathrm{it}} \sum \mathrm{e}_{\mathrm{it}}
\end{gathered}
$$

Where:

PAT $=$ Profit after tax (Dependent variable)

STD $=$ Shot term debt (Independent variable)

LTD $=$ Long term debt Independent variable)

$\mathrm{e}_{\mathrm{it}}=$ The error term

$\beta_{0}=$ Constant term (Intercept)

$\beta_{1}-\beta_{2}=$ Coefficient of independent variable

$\mu=$ Error term

Decision Rule

Accept the alternative hypothesis, if the P-value of the test is less than 0.05. Otherwise accept Ho.

\section{Presentation and Analysis of Data}

\subsection{Analysis of Data}

Table 1. Descriptive Statistics of the variables used in this study.

\begin{tabular}{llllll}
\hline & N & Minimum & Maximum & Mean & $\begin{array}{l}\text { Std. } \\
\text { Deviation }\end{array}$ \\
\hline PAT & 85 & 6.40 & 10.81 & 8.5449 & .70347 \\
LTD & 71 & .00 & 10.71 & 8.8852 & 1.30675 \\
STD & 57 & 8.02 & 10.66 & 9.1491 & .56780 \\
Valid N & 57 & & & & \\
(listwise) & & & & & \\
\hline
\end{tabular}

From table 1 above, the mean serves as a tool for setting benchmark. The median re-ranks and takes the central tendency. While the maximum and minimum values help in 
detecting problem in a data.

The standard deviation shows the deviation/dispersion/variation from the mean. It is a measure of risk, the higher the standard deviation, the higher the risk.

The standard deviation is a measure that summarizes the amount by which every value within a dataset varies from the mean. It is the most robust and widely used measure of dispersion. When the values in a dataset are pretty tightly bunched together, the standard deviation is small. In many datasets, the values deviate from the mean value due to chance and such datasets are said to display a normal distribution. In a dataset with a normal distribution, most of the values are clustered around the mean, while relatively few values tend to be extremely high or extremely low.

\subsection{Test of Hypotheses}

Hypothesis One

Ho: Short term debt does not significantly effect profit of quoted beverage companies in Nigeria.

Table 2. ANOVA ${ }^{a}$.

\begin{tabular}{llllll}
\hline Model & & Sum of Squares & df & Mean Square & Sig. \\
\hline \multirow{3}{*}{1} & Regression & 8.569 & 1 & 8.569 & 82.908 \\
& Residual & 5.685 & 55 & $.000^{\mathrm{b}}$ & \\
& Total & 14.254 & 56 & & \\
\hline
\end{tabular}

a. Dependent Variable: PAT.

b. Predictors: (Constant), STD.

Table 3. Coefficients ${ }^{a}$.

\begin{tabular}{llllll}
\hline \multirow{2}{*}{ Model } & & \multicolumn{2}{l}{ Unstandardized Coefficients } & \multicolumn{2}{l}{ Standardized Coefficients } \\
\cline { 3 - 5 } & & B & Std. Error & Beta & \\
\hline \multirow{2}{*}{1} & (Constant) & 2.002 & .694 & & 2.887 \\
& STD & .689 & .076 & .775 & .006 \\
\hline
\end{tabular}

a. Dependent Variable: PAT.

In table 2 , it reveals that the p-value is 0.000 indicates that the hypothesis has positive influence and statistically significant at level of significance $(5 \%)$; hence $\mathrm{p}$-value of the test statistic is less than alpha $(.000<0.05)$.

In table 3 , the regressed coefficient correlation result shows that an evaluation of the financial performance of the explanatory variable (Beta Column) shows that short term debt is significant (Sig. $=0.775)$.
Since p-value of the test statistic is less than alpha, the study therefore, reject null hypotheses and uphold alternative hypothesis which state that short term debt has significant effect on profit of quoted beverage companies in Nigeria.

Hypothesis Two

Ho: long term debt does not significantly affect profit of quoted beverage companies in Nigeria.

Table 4. ANOVA

\begin{tabular}{lllllll}
\hline Model & & Sum of Squares & df & Mean Square & F & Sig. \\
\hline \multirow{2}{*}{1} & Regression & .651 & 1 & .651 & 1.422 \\
& Residual & 31.608 & 69 & .458 & $.237^{\mathrm{b}}$ \\
& Total & 32.259 & 70 & & \\
\hline
\end{tabular}

a. Dependent Variable: PAT.

b. Predictors: (Constant), LTD.

Table 5. Coefficients ${ }^{a}$.

\begin{tabular}{|c|c|c|c|c|c|c|}
\hline \multirow{2}{*}{ Model } & \multirow[b]{3}{*}{ (Constant) } & \multicolumn{2}{|c|}{ Unstandardized Coefficients } & \multirow{2}{*}{$\begin{array}{l}\text { Standardized Coefficients } \\
\text { Beta }\end{array}$} & \multirow{2}{*}{$\mathbf{t}$} & \multirow{2}{*}{ Sig. } \\
\hline & & B & Std. Error & & & \\
\hline \multirow{2}{*}{1} & & 7.825 & .556 & & 14.077 & .000 \\
\hline & LTD & .074 & .062 & .142 & 1.193 & .237 \\
\hline
\end{tabular}

a. Dependent Variable: PAT.

In table 4 , it reveals that the p-value is 0.237 indicates that the hypothesis has positive influence but not statistically significant at level of significance $(5 \%)$; hence p-value of the test statistic is greater than alpha $(.237>0.05)$.

In table 5 , the regressed coefficient correlation result shows that an evaluation of the financial performance of the explanatory variable (Beta Column) shows that short term debt is significant (Sig.= 0.142).

Since p-value of the test statistic is less than alpha, the study therefore, reject alternative hypotheses and uphold null hypothesis which state that long term debt has no significant effect on profit of quoted beverage companies in Nigeria.

\subsection{Discussion of Findings}

Based on the above result, this study showed that short term debt has positive significant influence on profit of quoted beverage companies in Nigeria while long term debt 
has no significant effect on profit of quoted beverage companies in Nigeria. Hypothesis one revealed that the pvalue is 0.000 indicates that the hypothesis has positive influence and statistically significant at level of significance $(5 \%)$; hence $\mathrm{p}$-value of the test statistic is less than alpha $(.000<0.05)$. reveals that the $\mathrm{p}$-value is 0.237 indicates that the hypothesis has positive influence but not statistically significant at level of significance (5\%); hence p-value of the test statistic is greater than alpha $(.237>0.05)$.

\section{Conclusion and Recommendations}

\subsection{Conclusion}

This study examines the effect of financial mix on profitability of beverage firms in Nigeria using regression analysis. The study observed that short term debt has positive significant influence on profit of quoted beverage companies in Nigeria while long term debt has no significant effect on profit of quoted beverage companies in Nigeria. The results are partially consistent or in line with previous studies since the short term debt and the profitability of the companies is not in conformity with long term debt and profitability of companies hence, there are a number of factors that might influencing the capital structure of companies which led to continuous borrowing from various external sources and this affects the capital structure of the firms.

\subsection{Recommendations}

Based on the findings of the study, the following recommendations were made:

1. Companies should prefer internal financing than external financing sources on debt financing.

2. Corporate firms should rely more on equity financing for funds rising for their operation and minimize their borrowing operations in order to avoid bankrupt.

\section{References}

[1] Foyeke, O. I., Olusola, F. S., \& Aderemi, A. K. (2016). Financial Structure and the Profitability of Manufacturing Companies in Nigeria. Journal of Accounting, Finance and Auditing Studies 2 (3), 56-63.

[2] Faris N. A. (2016). Capital structure and market power: Evidence from Jordanian Bank, Managing Global Transitions, 9 (3), 289-310.

[3] Modigliani, F. \& Miller, M. (1958). The cost of capital, corporation finance and the theory of investment. The American Economic Review, 48: 261-297.

[4] Pons-Sanz, V., Zuta, S., Venezia, I., Ravid, S. A., \& Ofer, A. (2004). When are preferred shares preferred? Theory and empirical evidence. International Center for Finance, Yale University. Working Paper, 03-19, http://ssrn.com/abstract=286782. Retrieved 11/11/2017.

[5] Ross, S. A., Westerfield, R. W. \& Jaffe, J. F. (2006). Fundamentals of Corporate Finance. 7th Edition, McGraw-
Hill - Irwin, Boston, United States.

[6] Pandey, I. M. (2001). Capital structure and the firm characteristics: Evidence from an emerging market. Working paper, Indian Institute of Management, Ahmedabad.

[7] Rahemen, A. Zulfiqar, \& Mustafa. (2007). Capital structure and profitability: A case of Islamabad stock exchange. International Review of Business Research Papers 3 (5): 347-61.

[8] Angahar, P. A \& Ivarave, J. I. (2016). Effect of capital structure on corporate profit. Evidence from cement manufacturing firms in Nigeria. International Journal of Academic Research in Accounting, Finance and Management Sciences, 6 (2), 159-168.

[9] Amr, A. (2014). Corporate strategy and capital structure: An empirical study of listed manufacturing firms in Saudi Arabia. A Thesis Submitted for the Degree of Doctor of Philosophy, Brunel Business School, Brunel University, 1-65.

[10] Alhassan, A., \& Seidu A. (2016). The determinants of the financing decisions of listed and non-listed firms in Ghana. Asian Economic and Financial Review 2 (7): 751-771.

[11] Hassan, J. H., Faisal, K., \& Muhammad, I. W. (2016). Impact of debt on profitability of firms; Evidence from non-financial sector of Pakistan, City University Research Journal, 06 (01), 70-80.

[12] Oladeji, T., Ikpefan, A. O and Olokoyo, F. O (2015). An empirical analysis of capital structure on performance of firms in the petroleum industry in Nigeria. Journal of Accounting and Auditing: Research \& Practice, 2015 (2015), 1-9.

[13] Wilcox, L. (2016). What is financial mix decision? http://business-finance.blurtit.com/583572/what-is-financialmix-decision. Retrieved 18/3/2017.

[14] Taiwo A. M. (2012) An empirical analysis of capital structure on firms' performance in Nigeria. International Journal of Advances in Management and Economics. 1 (5), 116-124.

[15] Teruel, P. J. G. \& Solano, P. M. (2007). Effects of working capital management on SME profitability. International Journal of Managerial Finance, 3 (2), 164-177.

[16] Tirole, J., (2005). Theory of corporate finance, Princeton University Press.

[17] Tagoe, N., Nyarko, E., \& Anuwa-Amarb, E, (2005). Financial challenges facing urban SMEs under financial sector liberalization in Ghana", Journal of Small Business Management, 43 (3), 331-343.

[18] Sogrob-Mira, F. (2005). How SME uniqueness affects capital structure. Small business economics, 25 (5), 447-457.

[19] Irvine, P. \& J. Rosenfeld (2000). Raising capital using monthly income preferred stock: market reaction and implications for capital structure theory, Financial Management Summer, 5-20.

[20] Hovakimian, Armen, Tim Opler, \& Sheridan Titman. (2001). The debt equity choice, Journal of Financial and Quantitative Analysis, 3, 1-24.

[21] Pratheepkanth, P. (2011). Capital structure and financial performance: Evidence from selected business companies in Colombo Stock Exchange, Sri Lanka. J. Arts Sci Commerce, 2, 171-183. 
[22] Zeitun, R. (2009). Ownership structure, corporate performance and failure: Evidence from panel data of emerging market: The case of Jordan. Corporate Ownership Control, 6, 96-114.

[23] Ubesie, M. C. (2016). The effect of capital structure on the financial performance of Nigerian quoted conglomerates. European Journal of Accounting, Auditing and Finance Research, 4 (6), 61-69.

[24] Lawal, B. A, Edwin, T. K., Monica, W. K. \& Adisa, M. K. (2014). Effects of capital structure on firm's performance: Empirical study of manufacturing companies in Nigeria. Journal of Finance and Investment Analysis, 3 (4), 2014, 3957.

[25] Oyetade A. M. (2014). Determinants of capital structure of Nigerian non financial firms. Thesis submitted for the degree of Master of Science in Business Administration, University of Northern British Columbia, 1-59.

[26] Naeem, U. H., Malik, M. I., Muhammad, A., \& Mehboob, H. (2014). Effects of working capital management on firm performance: An empirical study of non-financial listed firms in Pakistan. International Journal of Academic Research in Business and Social Sciences, 4 (6), 114-132.
[27] Nyanamba, S. O., Nyangweso, G. N., \& Omari, S. M. (2013). Factors that determine the capital structure among microenterprises: A case study of micro-enterprises in Kisii Town, Kenya. American International Journal of Contemporary Research, 3 (7); July 2013.

[28] Mwangi, J. K. (2013). The effect of funding structure on the financial performance of deposit taking microfinance institutions in Kenya. A research project submitted for the award of master of business administration degree, university of Nairobi, 1-55.

[29] Raheel, M., Shahnaz, A., Rauf, Bashir, A., \& Umara, N. (2013). Capital structure and financial performance: Evidence from Pakistan, Journal of Basic and Applied Scientific Research. 115.

[30] Thian, C. L. (2012). Determinants of capital structure: Empirical evidence from financial services listed firms in China. International Journal of Economics and Finance 4 (3), 191-112.

[31] Robert N. M. (2012). The other side of value: The gross profitability premium. Simon Graduate School of Business, University of Rochester, 1-73. 